\title{
Reflections on Conversations with Robert Bell and Michael Guerriere: What Is Relevant Research?
}

\section{Réflexions sur des conversations avec Robert Bell et Michael Guerriere : La recherche pertinente: qu'est-ce que c'est au juste?}

by ANTON HART

Publisher, Healthcare Policy

\begin{abstract}
Two decision-makers from the acute-care sector weigh in on the issue of relevant research. Between the two of them they look for patient-defined research, evidence to support the conclusions, information that can lead to interventions designed to improve quality and outcomes and defined control mechanisms to properly identify the practices that improved the system. Three examples are cited and discussed. The context is set by comments from one of Canada's leading researchers and the use of research from one of this decade's most lauded system turnarounds.
\end{abstract}

\section{Résumé}

Deux décideurs du secteur des soins actifs se prononcent sur la question de la recherche pertinente. À eux deux, ils cherchent des travaux de recherche axés sur le patient, des preuves pour étayer les conclusions, des renseignements pouvant mener à des interventions conçues pour améliorer la qualité et les effets, ainsi que des mécanismes de contrôle définis permettant de cerner les pratiques qui contribuent à améliorer 
le système. Trois exemples sont présentés et discutés. Le contexte est établi par les commentaires d'un éminent chercheur canadien et les données sur l'utilisation de la recherche proviennent d'une des transformations de systèmes les plus louangées de cette décennie.

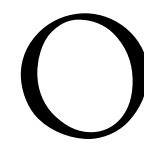
Ne year before the release of Healthcare Policy's inaugural issue, Morris Barer, Peter Coyte and I positioned the journal as one of "peerreviewed and relevant research." We wrote:

This journal will provide an important new outlet for peer-reviewed research of relevance to Canadian healthcare services. It will, more importantly, be designed to serve the evolving needs of health system decision-makers across the country looking for timely and relevant research, and new ideas, on the organization, financing, funding, management, regulation, delivery and use of health services for Canadians.

In short, it will provide a venue for peer-reviewed scholarly health services and policy research, debate and discussion that is accessible and useful to health system managers, policy makers and policy influencers. (Canadian Institutes of Health Research [CIHR] 2004)

A year later, introducing the first issue of this journal, Alan Bernstein,

"Policy makers have challenged the health system to develop more cost-effective, innovative and evidence-based ways of delivering care. President and CEO of the Canadian Institutes of Increasingly, Canada is moving towards an integrated and system-based approach to health service delivery. The health research community must also respond to similar challenges."

- Dr. Alan Bernstein, keynote address to the Canadian Academies of Health Sciences, September 21, 2005 Health Research, reinforced the idea: "Changing values, technologies and other circumstances demand constant, critical, objective and evidence-based change" (Bernstein 2005a).

To support researchers serving the evolving needs of health system decision-makers for timely and relevant research, the editorial advisory board of Healthcare Policy recommended a series of interviews and discussions with the journal's intended audience - decision-makers in healthcare. First to be interviewed was Dr. Brian Postl, President and CEO of Winnipeg Regional Health, who was 
recently appointed the prime minister's federal adviser on wait times. "Research," he told us, "is key in the process of change." He suggested "evidence" as one of four themes that the journal should consider as it looks at knowledge and its impact on policy and practice. The other themes were defining the audience, using appropriate tools to transfer and translate research, and translating research so that it is meaningful.

The present article reflects discussions with two more health system decisionmakers: Dr. Michael Guerriere and Dr. Robert Bell. Anticipating that we would explore "evidence," the topic was simply:"What is relevant research?"
"Rapid improvement is possible in healthcare, even in large, politically sensitive, financially stressed, publicly administered systems.
Improved healthcare quality, better service and reduced cost can (and should be) achieved at the same time. The conceptual underpinnings of change are straightforward; execution is the challenge!"
- Dr. K.W. Kizer, "Making and Sustaining Change in Healthcare," presentation, November 29, 2005

Dr. Guerriere, a physician who has always focused on systems and informatics, is at the heart of change in his role as Managing Partner at Courtyard Group - a meticulously selected line-up of experts advising providers of both healthcare policy and healthcare services. Courtyard Group's assignments are focused on the transformation of care and organizations for landmark clients in Canada, the United States and England. Dr. Guerriere is also Chair of the Ryerson University Board.

Dr. Bell, an orthopaedic surgeon specializing in cancer, is President and CEO of University Health Network (UHN) in Toronto, an organization with the explicit mission of providing exemplary patient care, research and education - a mission familiar to most academic health sciences centres. The scope of research and the complexity of cases in the network's care put Dr. Bell and his colleagues front and centre among patients and their families; researchers; providers of health policy, care and products; and the academic dons of both clinical and healthcare services.

Dr. Bell ${ }^{*}$ reflected on evidence-based research, dissemination and implementation. As CEO of an academic health sciences centre, he looks for patient-defined research, something he believes nurses do well. As an administrator, he points to the importance of CIHR's Pillar Three (health systems and services) and Pillar Four (social, cultural and other factors that affect the health of populations): researchers should look at improved efficiency, utility and productivity of the system and process - but

\footnotetext{
* based on a personal conversation with Dr. Bell.
} 
all in the context of the patient. The results, he says, can best be measured if they are built on a basis of evidence - something he's prepared to get from both grey literature and peer-reviewed journals.

As we discussed UHN's mission, Bell underscored the importance of being able to measure the organization's success at the highest level. A focus on the mission at the highest level sets up a process that is then passed down to departments and individual units. Properly executed, it leads to a common mission throughout the organization.

In short, Dr. Bell wants (1) patient-defined research to improve efficiency and utility, (2) the evidence that backs it up and (3) the ability to measure its impact.

Dr. Guerriere picks up this last point - the ability to measure results. Relevant

How did the Veterans Health Administration make research relevant? Consider the name of their research organization and its mission. Together they are very telling; you can see a whole strategy unfold."The mission of a special team of researchers - the Veterans Evidence-based Research, Dissemination, and Implementation Center (VERDICT) - is to improve the health of veterans by researching methods of optimizing the performance of the clinical micro-systems which surround and support the health care system-patient interface."

- Website for Veterans Evidence-based Research Dissemination Implementation Center, 2005 research, he says, provides information that should lead to an intervention that will or can improve outcomes; only then does research add value to our hospitals and healthcare system. Measurement can determine whether the intervention has utility and how well it works. Relevant research, furthermore, sets up control mechanisms so that, eventually, management can properly identify the practices that improved the system.

The quality and utility of research data are critical. They must be enabling; otherwise, why do the research? Guerriere cites the work of former New York Mayor Rudolph Giuliani. New York's CompStat program, which won the 1996 Innovations in Government Award from the Kennedy School of Government at Harvard University, allows police to monitor statistics on criminal activity on specific street corners as well as citywide, holding precinct commanders accountable for crime in their neighbourhoods. Because these data are updated constantly, the police can become proactive in fighting crime, curtailing trends before they become crime waves. Dr. Guerriere recommends Giuliani's book Leadership (2002) as a key to understanding the use of information to manage complex organizations. 
He then cites the work of Dr. Jack Tu and colleagues in the EFFECT Study (Canadian Cardiovascular Outcomes Research Team [CCORT] 2005), which focuses on a number of well-defined quality indicators that have demonstrably improved patient outcomes and provided direction and focus to quality improvement efforts for cardiac care. EFFECT is one of the largest and most comprehensive initiatives in the world to measure and improve the quality of cardiac care. Using a randomized

"The reality is that there is now an intimate, symbiotic and non-linear relationship between scientific understanding and its application into practice, products and policy. Initiatives like the Human Genome Project and the Grand Challenges in Global Health, initiated by the Gates Foundation, have gone a long way in blurring [the] post-World War II distinction between basic and applied research."

- Dr. Alan Bernstein, keynote address to the Canadian Academies of Health Sciences, September 21, 2005 trial of cardiac care report cards, the study's objective is to determine whether developing and publishing report cards based on clinical data collected from patient charts leads to greater use of evidence-based therapy at hospitals that receive them.

The fundamental purpose of the EFFECT Study is very specific: to assist in designing mechanisms to

reduce the delay between the acquisition of health research and evidence and their application in patient care. The intent is to raise awareness and provide information in a useful manner. By identifying both areas of high quality and areas for improvement, the study can support continued improvement in care as we strive for clinical excellence.

After phase I, the EFFECT researchers asked for feedback from participating hospitals and others in order to improve future reports. Phase II, involving a second round of chart abstraction, begins in late 2005; findings will be released in 2006-07. All quality indicators will be reviewed and revised as needed to ensure that they continue to reflect current evidence-based practice. Phase III - impact assessment involves a comparison of the hospitals performance between phases I and II. In their summary, Dr. Tu and colleagues write: "It is hoped that participating hospitals will view the EFFECT Study as a positive and constructive tool for change and that it will assist ongoing efforts to use the data for quality improvement initiatives" (CCORT 2005). That is relevant research, by Guerriere's standards.

He cites one more example of relevant research: the not-for-profit RAND Corporation, a major US think tank that, according to its own website, provides "objective analysis and effective solutions that address challenges facing the public and private sectors around the world." RAND conducts research in business, education, health, 
law and science in "areas ... that reflect the changing nature of global society," with the objective of providing readily accessible research and analysis to improve public policy and decision-making. Some of RAND's research is carried out on behalf of public and private sponsors and clients; other studies are undertaken under its own aegis.

One of the RAND Corporation's ongoing projects is the Promising Practices Network (PPN), an organization "dedicated to providing quality evidence-based information about what works to improve the lives of children, families and communities" (PPN 2005). According to its website:

PPN's target audience includes policy makers, service providers and other decision-makers at all levels who care about improving outcomes for children and families. The site helps decision-makers understand what approaches and programs have been shown in the scientific literature to improve outcomes in various areas such as child health and education.

PPN promises objective, evidence-based information; comprehensiveness; accessibility; and impartiality. It offers program summaries of effective interventions, clearly defining outcome areas and indicators, levels of evidence, evaluation methods and key findings. Funding sources are identified, and program bibliographies list all materials used to make judgments (PPN 2005).

Publishers should welcome such resources as the Promising Practices Network and its rich website. These can only reinforce our own mission to explore ideas, share best practices and enable excellence in healthcare.

Researchers who join us at Healthcare Policy will only reach individual decisionmakers like Dr. Bell and Dr. Guerriere if their research is relevant. Then, this journal will make a difference.

\section{REFERENCES}

Bernstein, A. 2005a."The Commitment to Knowledge Transfer." Retrieved December 14, 2005. $<$ http://www3.longwoods.com/product.php?productid $=17561 \&$ cat $=392 \&$ page $=1>$.

Bernstein, A. 2005b (September 21)."The Promise of the Health Sciences in the 21st Century." Keynote address to the Canadian Academies of Health Sciences. Retrieved December 14, 2005. <http://www.cihr-irsc.gc.ca/e/29662.html>.

Canadian Cardiovascular Outcomes Research Team (CCORT). 2005. "Enhanced Feedback for Effective Cardiac Treatment (EFFECT)." Retrieved December 14, 2005. <http://www.ices.on.ca/ webpage.cfm?site_id=18org_id=28morg_id=0\&gsec_id=398\&item_id=398\&category_id=29>. Canadian Institutes of Health Research (CIHR). 2004 (September). "New Canadian Health Services and Policy Journal: Announcement, Call for Expressions of Interest for Editorial Team, and 'Name That Journal' Contest." Retrieved December 14, 2005. <http://www.cihr-irsc.gc.ca/ e/24637.html>. 
Reflections on Conversations with Robert Bell and Michael Guerriere: What Is Relevant Research?

Giuliani, R.W. and K. Kurson. 2002. Leadership. New York: Hyperion.

Kizer, K.W. 2005 (November 29)."Making and Sustaining Change in Healthcare." Retrieved December 14, 2005. <http://www3.longwoods.com/home.php?cat $=105>$.

Promising Practices Network. 2005. Retrieved December 14, 2005. <http://www.promising practices.net/about_network.asp>.

Rand Coporation. 2005. “About Rand." Retrieved December 14, 2005. <http://www.rand.org/ about/>.

Veterans Evidence-based Research Dissemination Implementation Center (VERDICT). 2005. Mission statement and goals. Retrieved December 14, 2005. <http://verdict.uthscsa.edu/verdict/ default.htm >.

\section{The secret of knowing about it first.}

The Longwoods eLetter - ideas, policies, best practices, careers, transitions and learning events. Sign up here: http://longwoods.com/skin1/eletter.html

Longwoods Publishing

Enabling Excellence

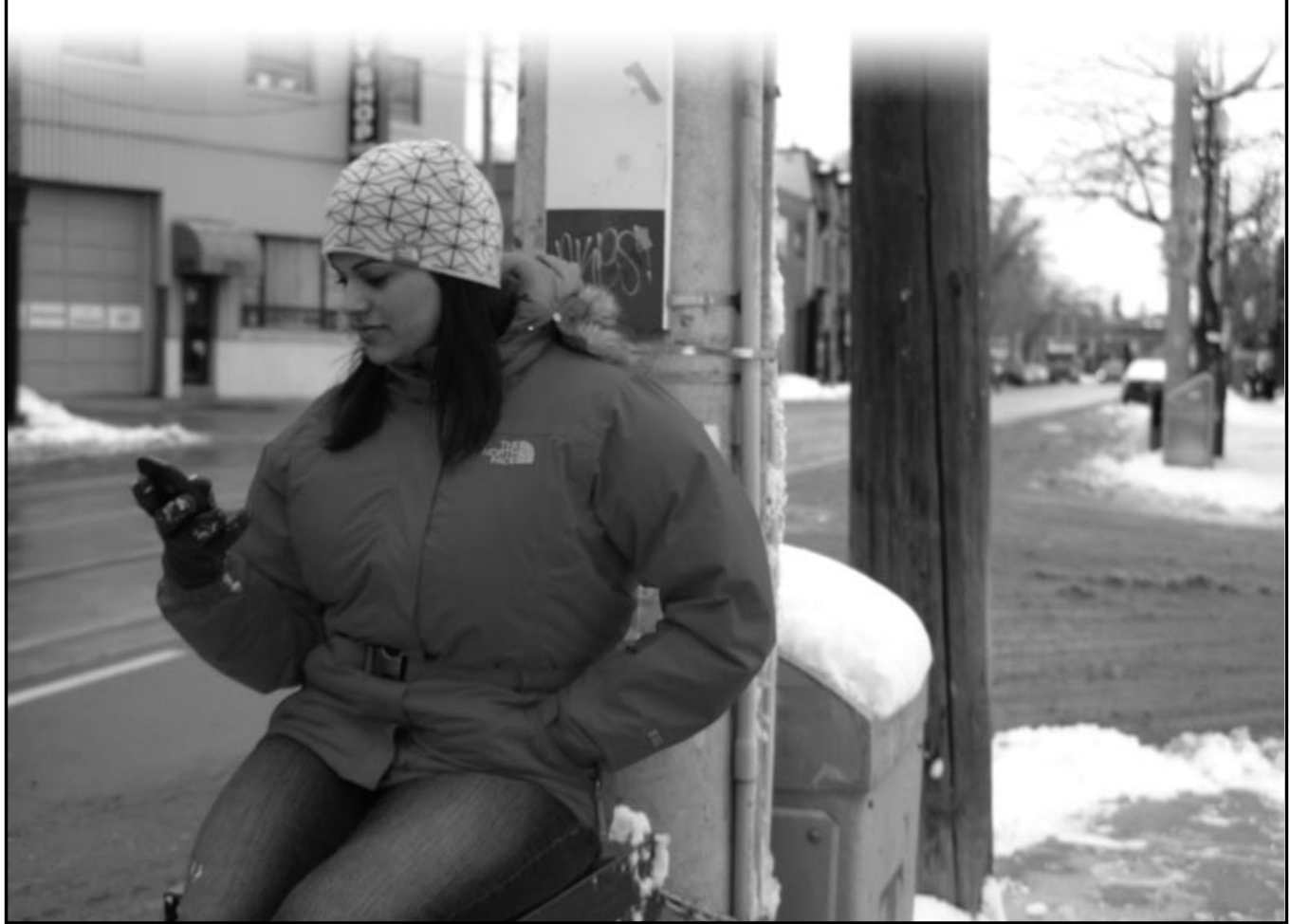

